\title{
EXPERIENCE WITH THE TREATMENT OF TROPHIC ULCERS BY PLASTER CASTS
}

\author{
Cynthia Fisher, M.B., B.S. \\ Lady Medical Officer, Nigeria Leprosy Service, Uzuakoli.
}

Ulcers on the sole of the foot present a very big problem to the leprosy worker, both in the Settlement and in local Segregation Villages. Their treatment entails endless work for dressers, and many patients despair of ever being able to walk about without bandaged feet. It is extremely difficulty to keep bandages clean, and secondary infection is common. The ideal treatment is complete rest for the foot, but here our difficulty must be a common one-our patients feel well in themselves and hate staying in bed. Many patients have been very co-operative and have stayed in bed, only to find on their discharge from hospital that their ulcers have quickly reappeared. Such patients are, not unnaturally, unwilling to embark on another round of hospital treatment.

In the past all types of dressing have been in use here-daily eusol, flavine, peroxide, dettol or cod liver oil; or weekly medicated dusting powder, flavine emulsion or dry dressings and strapping. All these have the disadvantage that the application is timeconsuming and entails frequent disturbance of the healing surface.

In order to deal with these difficulties, we have been using plaster-of-paris casts (below knee walking plasters) in the treatment of ulcers.

The treatment of chronic ulcers by plaster casts is a wellknown and old-established method, but there is little reference to it in the literature on leprosy.

The importance of rest has been stressed by Khan (5) but even though he used plaster of paris for immobilising the limb, the ulcers were still dressed through windows in the cast, and although the patients were allowed to walk about they did not lead normal lives.

Small plasters of salicylic acid resin have also been used (Haythornthwaite(4)) but these were more in the nature of a hardwearing dressing than a form of immobilisation.

Most writers (Maynard(1), Muir(2) and Lowe ${ }^{(3)}$ ) are agreed on the necessity for the removal of necrotic bone before the ulcer is able to heal. 
Treatment with plaster casts has the following theoretical advantages:-

(a) Complete rest for the foot is enșured.

(b) Very little time is required in treatment as the cast takes only a short time to apply, and maintenance is easy.

(c) The patient is mobile throughout treatment, and there is thus no temptation to stop treatment before the scar has consolidated.

\section{Selection of Cases}

Almost all ulcers below the knee were found suitable for this form of treatment, and age was no bar.

All sequestra were first removed, and we found that a week's course of daily eusol dressing was very useful in clearing up mild infections.

If the leg was oedematous, the patient was given two days' complete rest in bed to allow the swelling to subside.

A few patients had ulcers in congenitally deformed feet (e.g. talipes equino varus) but these were all fitted with casts which enabled them to walk comfortably.

\section{TECHNIQUE}

No suitable stockinette or walking irons were available.

Dry dressings were applied to the ulcer, and the limb bandaged very carefully from toes to knee with cotton bandages in lieu of stockinette. It is very important that the bandages should be applied without wrinkles as these encourage plaster sores, which, if neglected, are nearly as difficult to heal as the original ulcers.

Three six-inch and one four-inch plaster bandages were first applied for each cast over the cotton bandages, from below the knee to the base of the toes. This made a light firm plaster which could withstand patching without becoming unwieldy.

Small wooden rockers of a suitable size were made by our carpenter, and these were fixed to the plastered feet with two fourinch plaster bandages. Thus a total of three six-inch and three four-inch plaster bandages was used on each cast.

The patient was put to bed in the ward for forty-eight hours so that the plaster was thoroughly hard before he walked, and was seen again after twenty-four hours to ensure that the plaster was comfortable.

The rocker is an essential part of the treatment as it is necessary to keep the plaster dry by raising the foot from the ground. Wear of the rocker may be minimised by covering it with a layer of rubber. 


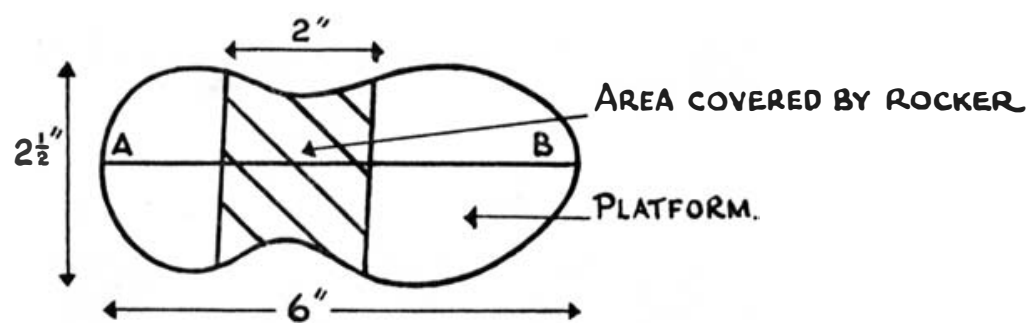

\section{SECTION ALONG LINE AB}

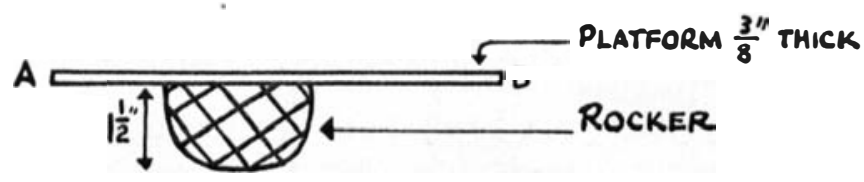

\section{MaintenANCE}

Constant supervision was necessary as the casts tended to wear through, and we have found a weekly plaster clinic most useful. A register of all patients with plasters was kept, and everyone reported to the clinic so that the Medical Officer could supervise repairs. Patients were encouraged to report to the Medical Officer at any time when their plaster cracked, so that an immediate repair could prevent the formation of a plaster sore. Those patients who for any reason (e.g. deformed hands) were unable to look after themselves, were not permitted to return to their normal houses in the Settlement, but were accommodated in two " plaster houses." These house four patients each, and are situated near the hospital so that the patients may be fed from the hospital kitchen.

\section{LENGTH OF TREATMENT}

The optimum time for treatment appears to be between three and four months. Most of our patients wore the same plaster during the whole of this time, and this was true even in the rainy season. Sometimes the children needed their plasters replaced after six weeks or so. 
RESULTS

(a) Healing of Ulcers.

The results of the first fifty cases inspected are shown in the table below.

TABLE

RESULTS OF PLASTER TREATMENT

Cundition of Ulcer on Removal of Plaster No. \%

Total (plasters removed) $\ldots \quad \ldots \quad \ldots \quad \ldots \quad 50$

Healed and ready for weight-bearing $\quad \ldots \quad 25 \quad 50$

$\begin{array}{llllllll}\text { Healed } & \ldots & \ldots & \ldots & \ldots & \ldots & \text { II } & 22\end{array}$

$\begin{array}{lllllllll}\text { Improved } & \ldots & \ldots & \ldots & \ldots & \ldots & 9 & \text { I8 }\end{array}$

$\begin{array}{llllllll}\text { No change } & \ldots & \ldots & \ldots & \ldots & \ldots & 5 & \text { I0 }\end{array}$

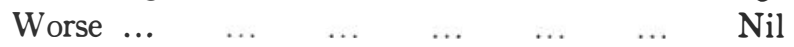

$\begin{array}{lllll}\text { Number still in plaster } \quad \ldots & \ldots & \ldots & \text { I5 }\end{array}$

$\begin{array}{llllll}\text { Total treated } \ldots & \ldots & \ldots & \ldots & \ldots & 65\end{array}$

All the plasters were applied and the results assessed by the writer, so that the standards applied throughout were uniform.

"Healed and ready for weight-bearing" indicates that the foot needed no protective dressing after the plaster was removed.

" Healed " means that there was no raw area, but the ulcer was not strong enough for the patient to walk barefoot, and dry dressings were worn for two or three weeks for protection.

" Improved" means that the ulcer was reduced in size.

All except two of those ulcers classified as healed have remained so till the time of writing (at least three months and some for as long as six months). Both these relapses occurred on congenitally deformed feet, and the ulcers were very small, and have now healed. They could have been prevented if the plaster had been left on for a few more weeks.

Of the sixty-five patients, forty-four had received treatment in hospital for their ulcer for varying periods, but the length of time in bed did not affect the results of plaster treatment. Eleven of these patients had been in bed for six months or longer, and it was the failure of other forms of treatment which induced the application of plaster.

(b) Others Effects.

(I) Most patients were able to live a more or less normal life, and requests for plaster treatment are multiplying.

(2) The perennial problem of having too many patients for 
too few hospital beds has been solved. We have released thirty of our eighty hospital beds for more important surgical cases.

(3) Many patients whose leprosy had been quiescent for as long as two years, but who had been detained because of ulcers, have been discharged and have now returned home.

(4) The number of staff required for dressing ulcers is considerably reduced, and we aim to close down our ulcer dressing room completely.

(5) Clinic patients can be admitted to the Settlement for treatment and returned to their Segregation Villages when their ulcers are healed.

\section{Conclusions}

We have found this method of treatment simple and practical, and, with proper safeguards, to be commended.

\section{REFERENCES}

(1) N. H. Maynard (April 1939). Leprosy Rview, Vol. IX, No. 2, p. 118.

(2) E. Muir (July 1943). Leprosy Review, Vol. XIV, No. 2, p. 49.

(3) J. Lowe and S. N. Chatter ji (October 1937). Leprosy in India, Vol. IX, No. 4, p. 115.

(4) H. M. Haythornthwaite (January 1943). Leprosy in India, Vol. XV, No. 1, p. 20.

(5) J. S. Khan (January 1939). Leprosy in India, Vol. XI, No. 1, p. 19. ACKNOWLEDGENENTS

I wish to express my thanks to the Director of Medical Services Eastern Region, Enugu, for permission to publish this paper, to Dr. T. F. Davey, Senior Specialist, Nigeria Leprosy Service, who suggested this work and gave encouragement and advice, and to all the patients who have co-operated so willingly. 